Article

\title{
Arsenic Fixation in Polluted Soils by Peat Applications
}

\author{
Antonio Aguilar-Garrido ${ }^{1, *(\mathbb{D}}$, Ana Romero-Freire ${ }^{2}{ }^{\mathbb{D}}$, Minerva García-Carmona ${ }^{3}$, \\ Francisco J. Martín Peinado ${ }^{1} \mathbb{D}$, Manuel Sierra Aragón ${ }^{1} \mathbb{D}$ and Francisco J. Martínez Garzón ${ }^{1}$ (D) \\ 1 Departamento de Edafología y Química Agrícola, Facultad de Ciencias, Universidad de Granada, \\ 18071 Granada, Spain; fjmartin@ugr.es (F.J.M.P.); msierra@ugr.es (M.S.A.); fjgarzon@ugr.es (F.J.M.G.) \\ 2 Instituto de Investigaciones Marinas (IIM-CSIC), 36208 Vigo, Pontevedra, Spain; anaromero@iim.csic.es \\ 3 Departamento de Agroquímica y Medio Ambiente, Universidad Miguel Hernández, \\ 03202 Elche, Alicante, Spain; minerva.garciac@umh.es \\ * Correspondence: antonioag@ugr.es; Tel.: +34-695-406-897
}

Received: 10 September 2020; Accepted: 27 October 2020; Published: 29 October 2020

\begin{abstract}
Soil arsenic (As) pollution is still a major concern due to its high toxicity and carcinogenicity, thus, the study of decontamination techniques, as the organic amendment applications, keeps upgrading. This research evaluates the potential remediation of peat in different As-polluted soils, by assessing the decrease of As solubility and its toxicity through bioassays. Obtained reduction in As solubility by peat addition was strongly related to the increase of humic substances, providing colloids that allow the complexation of As compounds. Calcareous soils have been the least effective at buffering As pollution, with higher As concentrations and worse biological response (lower soil respiration and inhibition of lettuce germination). Non-calcareous soils showed lower As concentrations due to the higher iron content, which promotes As fixation. Although in both cases, peat addition improves the biological response, it also showed negative effects, hypothetically due to peat containing toxic polyphenolic compounds, which in the presence of carbonates appears to be concealed. Both peat dose tested ( $2 \%$ and $5 \%$ ) decreased drastically As mobility; however, for calcareous soils, as there is no phytotoxic effect, the $5 \%$ dose is the most recommended; while for non-calcareous soils the efficient peat dose for As decontamination could be lower.
\end{abstract}

Keywords: soil remediation; toxicity bioassays; humic substances; calcium carbonate; iron oxides; polyphenolic compounds

\section{Introduction}

Soil pollution by potentially harmful elements (PHEs) is a worldwide problem with a diverse origin, e.g., waste generated by industrial, mining or smelting activities, intensive use of agrochemicals or wastewater irrigation [1,2]. Reducing the concentration of PHEs in soils is essential to minimize the current and future impacts produced on surrounding ecosystems. However, due to the high capacity of soil to retain contaminants, the cost and complexity of the existing techniques is a challenge not yet solved [3]. Therefore, intensive research is still necessary for the development of profitable, efficient, and environmentally responsible techniques. As Mirsal [1] states, the properties of the pollutants, the degree of pollution, and the natural processes that will take place in situ should be considered for selecting the remediation techniques. Some authors argue that remediation treatments must meet broad objectives, such as waste volume reduction efficiency, pollutant toxicity reduction efficiency, and profitability and environmental compliance [4].

Arsenic (As) is a metalloid found in highly variable concentrations in different environments [5]. By its hazard and presence worldwide, As highlights among the PHEs. Currently, its presence is 
associated with both natural and anthropogenic sources, and in many areas, its environmental levels in the water, sediments, or soils are of major concern due to its high toxicity that often threatens human health and ecosystems [6]. Besides, arsenic distribution also occurs in several biological species by direct uptake, thus, it can easily enter the food chain [7]. For all these reasons, many studies about arsenic pollution have been carried out, and pollution problems have been located in different regions of the world (hotspots), such as that found in soils of mining areas in China [8]; industrial complexes in, e.g., Korea [9], Spain [10], and Canada [11]; abandoned mine soils in Australia [12], Brazil [13], and Spain [14]; agroecosystems in Germany and France [15]; rice fields in major rice-growing countries (India, Bangladesh, China, Pakistan, Malaysia, Thailand, Japan, and Australia) [16]; and riverside areas of North East England [17]; among others.

Arsenic concentration in soils varies widely because it depends on the initial concentration (background) in the parent material, the natural geochemical cycles, and the type of soil [18]. According to the literature, the mean As values in natural soils varies from 0.1 to $80 \mathrm{mg} \cdot \mathrm{kg}^{-1}$ worldwide [19-22]. As far as government information is concerned, the guideline values proposed for soil protection vary greatly among countries and legislations. For example, the United States Environmental Protection Agency (EPA) establishes the permissible limit in $24 \mathrm{mg} \cdot \mathrm{kg}^{-1}$ [23]. Whereas in Andalusia (Spain), the Generic Reference Level (NGR) applicable to soils polluted with As is $36 \mathrm{mg} \cdot \mathrm{kg}^{-1}$ [24]. In Europe, other examples of As guideline values are $50 \mathrm{mg} \cdot \mathrm{kg}^{-1}$ [25], $76 \mathrm{mg} \cdot \mathrm{kg}^{-1}$ [26], and $43 \mathrm{mg} \cdot \mathrm{kg}^{-1}$ [27], for Germany, Netherlands, and United Kingdom, respectively.

Due to the elevated environmental levels of arsenic observed and the risks that it poses for human health, various technologies, both conventional and more advanced, are being used for arsenic removal from the soil and water systems [23]. In recent years, among them, stands out the soil/water phytoremediation, for being a technique that respects the environment $[28,29]$, and other bioremediation treatments, such as land farming, composting, and biopiles techniques [30]. Another interesting and frequently used methodology for the decontamination of PHEs is the amendments with organic compounds, which is characterized by being a highly viable method of reducing concentrations or toxic effects in polluted soils, and for being economical, efficient, and with good social acceptance [31-34]. The application of organic amendments in soils polluted by PHEs produces important changes in the main soil properties (e.g., increase $\mathrm{pH}$, boost organic carbon content, increment ion exchange capacity, raise soil moisture, and improve soil structure) and modifies the solubility and bioavailability of pollutants [3,35]. Likewise, treating soils contaminated with organic matter facilitates at the same time the activation of the nutrient cycle and the microorganisms involved; thus, that the ecosystemic functions that facilitate the long-term remediation of the soil are recovered. Some examples of this technique are the use of vermicompost [35,36], and, as different researchers point out [37-39], the use of peatland soils, characterized for their high potential to adsorb different metals such as Ni and $\mathrm{Sb}$ and the metalloid As present in waters. This high potential is likely due to peat having a large active surface area, a consequence of the high organic matter content, and thus a large number of adsorption sites. Additionally, adsorption is not the only feasible immobilization mechanism of PHEs as processes such as precipitation, coprecipitation, and complex formation are also expected and would aid retention $[38,40]$.

Although the aforementioned studies demonstrate its capacity to adsorb As present in water (natural water and mine wastewater) and atmospheric depositions, there is little research on the use of peat in the remediation of As-polluted soils. For this reason, the present study is focused on the assessment of the remediation capacity of the peat in As-polluted soils. Furthermore, to gain targeted information about its potential use in soil remediation projects, the proposed experiments will be carried out both in anthropogenically polluted soils (areas affected by a mining discharge that present significant residual pollution) [41] and in artificially polluted soils (natural soils that are polluted in the laboratory), selected from previous toxicity studies [42]. The specific aims will be (i) to determine the peat doses applicable to soils, depending on their typology, for effective and economical implementation of the remediation technique; (ii) the assessment of the As mobility and the evaluation 
of soil toxicity through the use of quick and economic toxicity bioassays (soil respiration and seed germination/root elongation of Lactuca sativa L. tests).

\section{Materials and Methods}

\subsection{Soil Samples}

Three soil samples were selected for this study: 1 soil polluted in situ, consisting of the surface layer (uppermost $20 \mathrm{~cm}$ ) of an eutric Regosol affected by residual pollution after the Aznalcóllar mine spill [43] and located in the Guadiamar Green Corridor (AZN); and 2 ex situ (spiked) soils, 1 sampled from the $C$ horizon of a calcaric Kastanozem (SC), and another from a $C$ horizon of a leptic Regosol (SNC), both samples were selected by their contrasting properties and were described in Romero-Freire et al. [44]. In all cases, soil samples were obtained from composite subsamples of the same horizon and thoroughly homogenized before the analysis. The 2 natural soil samples (SC and SNC) were selected due to the strong differences in the calcium carbonate content to study the role of carbonates in As fixation. AZN samples were taken in an area with high residual pollution, which has partially avoided remediation measures carried out in the area (i.e., the addition of carbonates, clays, and organic wastes) throughout these years [14].

The main parameters analyzed in the soil samples were: $\mathrm{pH}$ (soil:water ratio 1:2.5), electrical conductivity (EC) (soil:water ratio 1:5), calcium carbonate content $\left(\mathrm{CaCO}_{3}\right)$, organic carbon $(\mathrm{OC})$, textural analysis (clay content), cation exchange capacity (CEC), degree of base saturation (BS), bulk density (BD), porosity (Po), and available water (AW). The main physicochemical properties were analyzed according to standard analysis methods [45]. On the other hand, in addition to analyzing total iron content (Fet) by acid digestion in strong acids $\left(\mathrm{HNO}_{3}+\mathrm{HF}\right)$, free iron content (Fed) and amorphous iron content (Feo) were also analyzed following the Holmgren [46] and Blakemore [47] techniques, respectively. All analyses were done in triplicate.

\subsection{Peat Characterization}

The organic compound selected for remediation treatments in the As-polluted soil samples was peat from the Agia's peat bog located in Padul (Granada, Spain), which is an acidic minerotrophic peat bog (or fen type). To have a correct characterization of the peat, the same properties and same analytical techniques as for soils have been applied (Table 1). Besides, the fractionation of the organic carbon (OC) presented in the peat was determined, according to Kononova [48], by the determination of the Total Humic Extract (THE), Humic Acids (HA), and Fulvic Acids (FA). The polyphenolic profile of the peat was determined by high-performance liquid chromatography (HPLC) using an Agilent 1200 series ${ }^{\circledR}$ HPLC-DAD-ESI-MS n (Agilent Technologies, Inc.(R), Santa Clara, CA, USA). All peat analyzes were carried out in triplicate.

\subsection{Soil Samples Preparation}

The SC and SNC soil samples were spiked with sodium arsenate solutions $\left(\mathrm{Na}_{2} \mathrm{HAsO}_{4} \times 7 \mathrm{H}_{2} \mathrm{O}\right)$ at different concentration ranges $\left(0,300\right.$, and $\left.600 \mathrm{mg} \cdot \mathrm{kg}^{-1} \mathrm{As}\right)$ under controlled laboratory conditions. The selected concentrations (well above the permissible limits in soils) were chosen according to the first guideline values proposed for Andalusia in the industrial areas ( $\left.300 \mathrm{mg} \cdot \mathrm{kg}^{-1} \mathrm{As}\right)$, and multiplying the highest concentrations of industrial areas by 2, which had been used in Romero-Freire et al. [42] where As toxicity in relation to soil properties was studied. Once spiked, soil samples were incubated for 4 weeks under controlled humidity and temperature conditions to stabilizing the added pollutant and optimizing the time consumption according to previous observations $[41,49,50]$.

After soil incubation, different peat treatments were applied. Peat doses selected were $0 \%, 2 \%$, and $5 \%$ with respect to the total dry weight of the samples. These doses were in relation to the organic amendments used in the Aznalcóllar soil remediation [51] and other restoration plans of mining 
areas [52]. After the application of these amendments, samples were incubated again for another 4 weeks, under the same conditions.

Table 1. Main properties of the selected soil samples and peat (mean \pm standard deviation).

\begin{tabular}{|c|c|c|c|c|}
\hline Properties & AZN & SC & SNC & Peat \\
\hline $\mathrm{pH}\left(\mathrm{H}_{2} \mathrm{O}, 1: 2.5\right)$ & $6.77 \pm 0.07$ & $8.79 \pm 0.02$ & $5.87 \pm 0.09$ & $3.50 \pm 0.14$ \\
\hline $\mathrm{EC}^{2}\left(\mathrm{dS} \cdot \mathrm{m}^{-1}\right)$ & $0.40 \pm 0.01$ & $0.07 \pm 0.01$ & $0.05 \pm 0.01$ & $3.10 \pm 0.21$ \\
\hline $\mathrm{CaCO}_{3}{ }^{3}(\%)$ & $0.53 \pm 0.04$ & $92.32 \pm 0.86$ & $\mathrm{nd}^{1}$ & nd $^{1}$ \\
\hline $\mathrm{OC}^{4}(\%)$ & $0.72 \pm 0.13$ & $0.38 \pm 0.17$ & $0.49 \pm 0.02$ & $25.04 \pm 0.05$ \\
\hline Clay (\%) & $8.81 \pm 0.40$ & $7.70 \pm 0.58$ & $8.31 \pm 0.12$ & nd $^{1}$ \\
\hline $\mathrm{CEC}^{5}\left(\mathrm{cmol}_{+} \mathrm{kg}^{-1}\right)$ & $8.46 \pm 0.16$ & $2.94 \pm 0.13$ & $3.83 \pm 0.37$ & $41.77 \pm 1.16$ \\
\hline $\mathrm{BS}^{6}(\%)$ & $97.10 \pm 1.12$ & $100.00 \pm 0.00$ & $30.70 \pm 1.05$ & $66.24 \pm 3.35$ \\
\hline $\mathrm{BD}^{7}\left(\mathrm{~g} \cdot \mathrm{cm}^{-3}\right)$ & $1.56 \pm 0.01$ & $1.53 \pm 0.02$ & $1.57 \pm 0.003$ & $0.32 \pm 0.006$ \\
\hline $\mathrm{Po}^{8}(\%)$ & $41.30 \pm 0.51$ & $37.75 \pm 0.92$ & $40.60 \pm 0.10$ & $83.74 \pm 0.01$ \\
\hline $\mathrm{AW}^{9}(\%)$ & $7.18 \pm 0.04$ & $5.38 \pm 0.06$ & $7.40 \pm 0.03$ & $8.51 \pm 0.01$ \\
\hline $\mathrm{As}_{\mathrm{T}}{ }^{10}\left(\mathrm{mg} \cdot \mathrm{kg}^{-1}\right)$ & $120.20 \pm 0.14$ & $3.39 \pm 0.15$ & $4.39 \pm 0.10$ & $11.85 \pm 0.10$ \\
\hline $\mathrm{As}_{\mathrm{W}}{ }^{11}\left(\mathrm{mg} \cdot \mathrm{kg}^{-1}\right)$ & $0.03 \pm 0.01$ & $0.01 \pm 0.001$ & $0.01 \pm 0.001$ & $0.03 \pm 0.001$ \\
\hline Fet ${ }^{12}\left(\mathrm{~g} \cdot \mathrm{kg}^{-1}\right)$ & $68.40 \pm 0.31$ & $16.80 \pm 0.35$ & $71.20 \pm 0.12$ & $14.40 \pm 0.06$ \\
\hline Fed ${ }^{13}\left(\mathrm{~g} \cdot \mathrm{kg}^{-1}\right)$ & $26.30 \pm 0.25$ & $3.30 \pm 0.03$ & $7.80 \pm 0.10$ & $0.97 \pm 0.04$ \\
\hline Feo ${ }^{14}\left(\mathrm{~g} \cdot \mathrm{kg}^{-1}\right)$ & $18.80 \pm 0.21$ & $0.01 \pm 0.01$ & $1.00 \pm 0.06$ & $0.43 \pm 0.06$ \\
\hline $\operatorname{THE}^{15}(\%)$ & - & - & - & $27.26 \pm 0.30$ \\
\hline $\mathrm{HA}^{16}(\%)$ & - & - & - & $22.64 \pm 0.20$ \\
\hline $\mathrm{FA}^{17}(\%)$ & - & - & - & $4.62 \pm 0.30$ \\
\hline
\end{tabular}

1 non-detected; ${ }^{2}$ electrical conductivity; ${ }^{3}$ calcium carbonate content; ${ }^{4}$ organic carbon content; ${ }^{5}$ cation-exchange capacity; ${ }^{6}$ degree of base saturation; ${ }^{7}$ bulk density; ${ }^{8}$ porosity; $;{ }^{9}$ available water; ${ }^{10}$ total arsenic concentration; ${ }^{11}$ water-soluble arsenic concentration; ${ }^{12}$ total iron; ${ }^{13}$ free iron; ${ }^{14}$ amorphous iron; ${ }^{15}$ Total Humic Extract; ${ }^{16}$ Humic Acid; ${ }^{17}$ Fulvic Acid.

After the incubation period, water-soluble extracts (1:1) were done from treated soils. In the obtained extracts $\mathrm{pH}\left(\mathrm{pH}_{\mathrm{W}}\right)$, electrical conductivity $\left(\mathrm{EC}_{\mathrm{W}}\right)$ were measured with a $\mathrm{pH} /$ conductometer 914 Metrohm (Metrohm AG, Herisau, Switzerland) and a Eutech ${ }^{\mathrm{TM}}$ CON700 (Thermo Fisher Scientific Inc., Waltham, MA, USA) conductivity-meter, respectively, and soluble arsenic concentration (Asw) was measured by inductively coupled plasma-mass spectrometry (ICP-MS) in a spectrometer PerkinElmer ${ }^{\circledR}$ NexIONTM 300D (Waltham, MA, USA).

In total, 105 treatments were carried out in the 3 different groups of samples: $15 \mathrm{AZN}$ ( 5 soil samples $\times 3$ peat treatments), 45 SC ( 5 soil samples $\times 3$ As treatments $\times 3$ peat treatments), and 45 SNC ( 5 soil samples $\times 3$ As treatments $\times 3$ peat treatments). Each treatment was identified as follows: First, an acronym representing the soil sample considered (AZN, SC, SNC), separated by a hyphen the number that identifies the content in As added $\left(0,300,600 \mathrm{mg} \cdot \mathrm{kg}^{-1}\right)$ and separated by another hyphen the percentage of peat added $(0 \%, 2 \%, 5 \%)$.

\subsection{Determination of As Concentrations}

Total arsenic concentration $\left(\mathrm{As}_{\mathrm{T}}\right)$ was determined from acid digestion in strong acids $\left(\mathrm{HNO}_{3}+\mathrm{HF}\right)$, and water-soluble arsenic concentration $\left(\mathrm{As}_{\mathrm{W}}\right)$ was determined from the soil:water extracts (1:1 ratio). In all cases, As was measured by ICP-MS in a spectrometer PerkinElmer ${ }^{\circledR}$ NexIONTM 300D (Waltham, MA, USA). Instrumental drift was monitored by regularly running standard element solutions between samples. For calibration, 2 sets of standards containing the analyte of interest at 5 concentrations were prepared using rhodium as an internal standard. Procedural blanks for estimating the detection limits $(3 \times \sigma ; n=6)$ were $<0.21 \mu \mathrm{g} \cdot \mathrm{L}^{-1}$ for As. The analytical precision was better than $\pm 5 \%$ in all cases.

\subsection{Toxicity Bioassays}

To evaluate the soil toxicity after peat treatments, 2 short-term toxicity bioassays were selected: 
1. Heterotrophic soil respiration was measured by determining the $\mathrm{CO}_{2}$ flux from treated soils with a microbiological analyser $\mu$-Trac 4200 SY-LAB model (Neupurkersdorf, Austria) according to ISO 17155 protocol [53]. Soil moisture content was fixed at field capacity and soils were incubated at a constant temperature of $30^{\circ} \mathrm{C}$. The production of $\mathrm{CO}_{2}$ was determined by absorption in vials with a solution of potash ( $\mathrm{KOH} 0.2 \%)$ during $96 \mathrm{~h}$, and related to the mass of soil used to obtain a measure of respiration rate. The results were expressed as the basal respiration rate (BR) in $\mathrm{mg} \cdot \mathrm{CO}_{2} \cdot \mathrm{day}^{-1} \cdot \mathrm{kg}^{-1}$.soil. This test was done in triplicate in all studied soil treatments and also using only peat samples.

2. Seed germination/root elongation of Lactuca sativa L. toxicity test, according to OECD [54] and US EPA [55] recommendations. This test assessed the phytotoxic effects on seed germination and seedling growth in the first days of growth [56]. In Petri dishes, 15 seeds of Lactuca sativa L. and $5 \mathrm{~mL}$ of soluble extract from the treated soils were placed in an incubator at $25 \pm 1{ }^{\circ} \mathrm{C}$, and the number of germinated seeds and the length of the germinated seed roots were measured after $120 \mathrm{~h}$. Two endpoints were calculated: (a) The percentage of germinated seeds (SG) in relation to the control, and (b) the percentage of root elongation (RE) in relation to the control (distilled water). This assay was done in triplicate in all treatments.

\subsection{Data Analyses}

Normality was checked with the Shapiro-Wilk test and homoscedasticity with the Levene test. As none of these conditions were met, even when transforming the variables, non-parametric Kruskal-Wallis and Mann-Whitney U test $(p<0.05)$ for the analysis of multiple comparisons were applied. Furthermore, in order to analyze the influence of soil properties on the solubility and toxicity of arsenic, Spearman correlation analysis involving soil properties, peat doses added, water-soluble arsenic concentrations, and endpoints of the toxicity bioassays (BR, SG, and RE) were also performed. All these analyses were performed with a confidence level of $95 \%$ by using SPSS v.21.0 software (SPSS Inc. ${ }^{(\mathrm{R})}$, Chicago, IL, USA).

\section{Results}

\subsection{Properties of the Soil and Peat Samples}

Results observed for the Aznalcóllar polluted field soil (AZN) showed slightly acidic pH, low content of carbonates $(<1 \%)$, and moderate electrical conductivity. Whereas the As level $\left(>100 \mathrm{mg} \cdot \mathrm{kg}^{-1}\right)$ and the levels of iron oxides (Fed and Feo) were higher than in the reference soils. The reference soils (SC and SNC) differed from each other by the content of carbonates, $\mathrm{pH}$, degree of base saturation, and the contents in the different forms of Fe, with much higher Fe contents in the SNC samples. The total $\mathrm{As}\left(\mathrm{As}_{\mathrm{T}}\right)$ concentrations were similar, with average content below the considered background level of $29 \mathrm{mg} \cdot \mathrm{kg}^{-1}$ [57] (Table 1).

The peat selected had an acidic $\mathrm{pH}$, a high electrical conductivity of $3.10 \mathrm{dS} \cdot \mathrm{m}^{-1}$, and a degree of base saturation of more than 50\%; it showed low bulk density (BD) and, consequently, high porosity (Po). The organic carbon content (OC) was $25.04 \%$, of which $27.26 \%$ corresponds to Total Humic Extract (THE). This THE was divided into 22.64\% Humic Acids (HA) and $4.62 \%$ Fulvic Acids (FA). Peat showed a total iron content (Fet) of $14.40 \mathrm{~g} \cdot \mathrm{kg}^{-1}$, and As of $11.85 \mathrm{mg} \cdot \mathrm{kg}^{-1}$, of which $0.03 \mathrm{mg} \cdot \mathrm{kg}^{-1}$ was soluble in water $(<1 \%)$ (Table 1$)$. The polyphenolic profile of the peat identifies three compounds: 4-hydroxybenzoic-4-glucoside acid (662 $\left.\mathrm{mg} \cdot \mathrm{kg}^{-1}\right), \mathrm{p}$-coumaroylquinic acid $\left(1222 \mathrm{mg} \cdot \mathrm{kg}^{-1}\right)$, and lariciresinol-sesquilignan $\left(4783 \mathrm{mg} \cdot \mathrm{kg}^{-1}\right)$, representing $0.66 \% \mathrm{w} / \mathrm{w}$ of the total peat, with the phenolic compound lariciresinol-sesquilignan being the most abundant (Figure S1).

\subsection{Arsenic Solubility}

The leachate from the AZN samples showed acidic $\mathrm{pH}_{\mathrm{W}}$ without statistically significant differences among the peat treatments. Whereas, $\mathrm{EC}_{\mathrm{W}}$ increased significantly with additions of $2 \%$ and $5 \%$ of 
peat ( 0.44 and $0.53 \mathrm{dS} \cdot \mathrm{m}^{-1}$, respectively). In SC soils spiked with As, the addition of peat decreased the $\mathrm{pH}_{\mathrm{W}}$ significantly. Similar results were obtained in the SNC samples, but with lower $\mathrm{pH}_{\mathrm{W}}$ values. In addition, it was observed that the addition of As significantly increased the $\mathrm{pHw}$ due to the fact that $\mathrm{As}$ had been added in the form of sodium arsenate solutions $\left(\mathrm{Na}_{2} \mathrm{HAsO}_{4} \times 7 \mathrm{H}_{2} \mathrm{O}\right)$. Regarding the $\mathrm{EC}_{\mathrm{W}}$, it was observed that in almost all treatments with As and peat, the EC of the leachates increased significantly, except in the SNC-300-2 and SNC-600-2 treatments, where there were no significant differences (Table 2).

Table 2. The $\mathrm{pH}_{\mathrm{W}}$, electrical conductivity $\left(\mathrm{EC}_{\mathrm{W}}\right)$ in water-soluble extract (1:1), and water-soluble As content $\left(\mathrm{As}_{\mathrm{W}}\right)$ in the three studied soil samples with the different addition of As and peat (mean \pm standard deviation).

\begin{tabular}{|c|c|c|c|c|c|c|c|}
\hline \multirow{2}{*}{$\begin{array}{c}\text { Soil } \\
\text { As }\left(\mathrm{mg} \cdot \mathrm{kg}^{-1}\right)\end{array}$} & \multirow{2}{*}{$\begin{array}{l}\text { AZN } \\
120.2\end{array}$} & \multicolumn{3}{|c|}{ SC } & \multicolumn{3}{|c|}{ SNC } \\
\hline & & 0 & 300 & 600 & 0 & 300 & 600 \\
\hline Peat $(\%)$ & \multicolumn{7}{|c|}{$\mathrm{pH}_{\mathrm{W}}(1: 1)$} \\
\hline 2 & $4.59 \pm 0.08 \mathrm{a}$ & $7.08 \pm 0.02 \mathrm{aA}$ & $7.20 \pm 0.09 \mathrm{aAB}$ & $7.31 \pm 0.02 \mathrm{bB}$ & $3.72 \pm 0.09 \mathrm{aB}$ & $5.46 \pm 0.09 \mathrm{aA}$ & $5.67 \pm 0.08 \mathrm{aA}$ \\
\hline 5 & $4.67 \pm 0.08 \mathrm{a}$ & $6.90 \pm 0.02 \mathrm{aA}$ & $7.02 \pm 0.09 \mathrm{aAB}$ & $7.13 \pm 0.02 \mathrm{aB}$ & $3.64 \pm 0.10 \mathrm{aB}$ & $5.32 \pm 0.09 \mathrm{aA}$ & $5.53 \pm 0.07 \mathrm{aA}$ \\
\hline Peat (\%) & \multicolumn{7}{|c|}{$\mathrm{EC}_{W}(1: 1)\left(\mathrm{dS} \cdot \mathrm{m}^{-1}\right)$} \\
\hline 2 & $0.44 \pm 0.07 b$ & $0.19 \pm 0.01 \mathrm{bA}$ & $0.52 \pm 0.01 \mathrm{bB}$ & $0.95 \pm 0.03 \mathrm{abC}$ & $0.10 \pm 0.01 \mathrm{bA}$ & $0.19 \pm 0.01 \mathrm{aB}$ & $0.33 \pm 0.01 \mathrm{aC}$ \\
\hline 5 & $0.53 \pm 0.07 c$ & $0.28 \pm 0.02 \mathrm{cA}$ & $0.61 \pm 0.00 \mathrm{cB}$ & $1.01 \pm 0.03 \mathrm{bC}$ & $0.19 \pm 0.01 \mathrm{cA}$ & $0.28 \pm 0.02 \mathrm{bB}$ & $0.42 \pm 0.01 \mathrm{bC}$ \\
\hline Peat (\%) & \multicolumn{7}{|c|}{$\operatorname{As}_{W}(1: 1)\left(\mathrm{mg} \cdot \mathrm{kg}^{-1}\right)$} \\
\hline 0 & $0.026 \mathrm{~b}$ & $0.010 \mathrm{bA}$ & $152.513 \mathrm{bB}$ & $337.450 \mathrm{bC}$ & $0.019 \mathrm{bA}$ & $26.427 \mathrm{bB}$ & $118.123 \mathrm{bC}$ \\
\hline 2 & $0.014 \mathrm{a}$ & $0.004 \mathrm{aA}$ & $0.759 \mathrm{aB}$ & $2.588 \mathrm{aC}$ & $0.015 \mathrm{abA}$ & $0.450 \mathrm{aB}$ & $2.592 \mathrm{aC}$ \\
\hline
\end{tabular}

Lowercase letters indicate statistically significant differences for each As treatment with different peat additions; and capital letters among the different treatments with As for the same peat content (Kruskal-Wallis test, $p<0.05$ ).

Soluble As $\left(\mathrm{As}_{\mathrm{W}}\right)$ decreased significantly with peat treatments, regardless of the percentage of peat applied and for all treatments with As. In AZN-0, As $\mathrm{W}_{\mathrm{W}}$ was low $\left(0.026 \mathrm{mg} \cdot \mathrm{kg}^{-1}\right)$; even so, the peat treatments significantly decreased the As solubility, with a reduction of $46.15 \%$ in AZN-2 and $50.00 \%$ in AZN-5 compared to AZN-0, respectively. In the reference soils, once polluted, different amounts of $\mathrm{As}_{\mathrm{W}}$ were obtained but far from the total As added, showing SC higher As $\mathrm{w}_{\mathrm{W}}$ than SNC. In SC-300-0 and SC-600-0, the reduction of As ${ }_{W}$ in relation to the dose of As added was 49.16\% and 43.76\%, respectively; and in SNC-300-0 and SNC-600-0, the reduction was 91.99\% and 80.31\%, respectively. The addition of peat significantly enhanced arsenic retention. Peat additions at $2 \%$ and $5 \%$ decreased As $s_{W}$ with respect to the no addition by more than $98 \%$ in all samples. This decrease in $\mathrm{As}_{\mathrm{W}}$ was even observed, and significantly, in the reference soil samples when adding peat (Table 2).

\subsection{Assessment of Peat Treatments Adequacy from Bioassays. Arsenic Solubility}

\subsubsection{Basal Soil Respiration}

The basal soil respiration test was also done with the peat alone, showing basal respiration (BR) values of $101.84 \pm 9.94 \mathrm{mg} \cdot \mathrm{CO}_{2} \cdot \mathrm{day}^{-1} \cdot \mathrm{kg}^{-1} \cdot$ soil. BR increased significantly as the amount of peat added increased in AZN soils. In calcareous samples (SC), the increase in pollution without peat additions (SC-300-0 and SC-600-0) showed a slight, but not significant, decrease in BR. Peat additions significantly increased BR up to about $100 \mathrm{mg} \cdot \mathrm{CO}_{2} \cdot \mathrm{day}^{-1} \cdot \mathrm{kg}^{-1}$. soil. Peat at $2 \%$ significantly increased BR compared to the no peat addition. Peat at $5 \%$ further increased the respiration rate, with significant differences among the three As treatments. Similar results were obtained in the non-calcareous samples (SNC) with higher levels in BR than in SC. Treatment with $2 \%$ of peat considerably increased the BR, being higher in the reference sample and decreasing significantly with As addition. The addition of $5 \%$ of peat showed a significantly increases BR with values $>100 \mathrm{mg} \cdot \mathrm{CO}_{2} \cdot \mathrm{day}^{-1} \cdot \mathrm{kg}^{-1} \cdot \mathrm{soil}$. Comparing the 
results obtained for the same pollution level with increasing peat dose, significant differences appeared between SNC-300-2 and SNC-300-5, and between SNC-600-2 and SNC-600-5 (Figure 1).

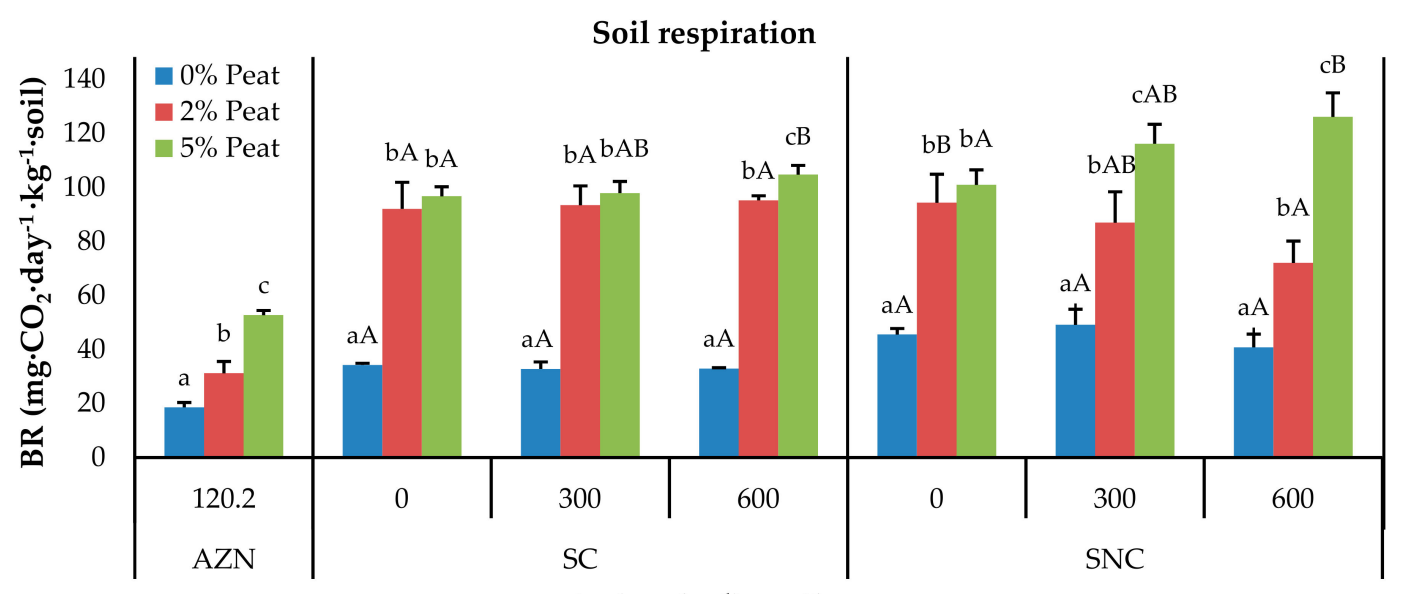

As $\left(\mathrm{mg} \cdot \mathrm{kg}^{-1}\right)$ - soils

Figure 1. Basal respiration rate (BR) for soil samples with different treatments. Lowercase letters indicate statistically significant differences for each treatment with different peat additions; and capital letters among the different treatments with As for the same peat content (Kruskal-Wallis test, $p<0.05$ ).

\subsubsection{Germination and Elongation Test with the Lactuca Sativa L. Plant}

AZN soil showed a low germination rate for AZN-0 and AZN-2, respectively, and even lower for the higher peat treatment (AZN-5), but without significant differences between peat treatments. In SC soils, without As addition, reported germination of $100 \%$, whereas with As addition, it completely inhibits the Lactuca sativa L. seed germination (Figure 2). The addition of peat in the polluted SC soil entailed a high germination rate. In non-calcareous soil (SNC), the germination test showed substantially different results compared to calcareous soil (SC). When there was no addition of peat, the germination of Lactuca sativa L. occurred in the three As treatments. In both SNC-0-0 and SNC-300-0, the germination was $100 \%$, while in the SNC-600-0, germination decreased significantly by $43 \%$. Besides, peat treatments decreased SG in all treatments without showing significant differences due to the high dispersion in the data (error bars).

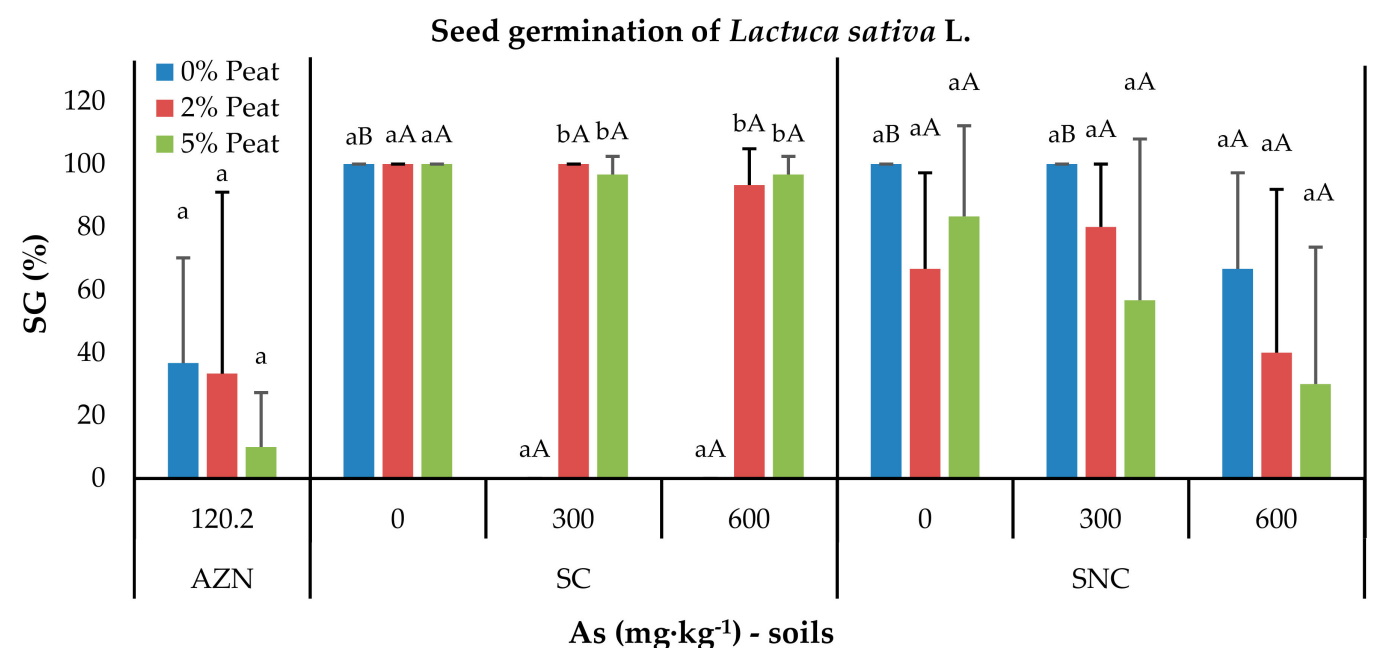

Figure 2. Percentage of germination for Lactuca sativa L. seeds (SG\%) exposed to the different soils and treatments. Lowercase letters indicate statistically significant differences for each treatment with different peat additions; and capital letters among the different treatments with As for the same peat content (Kruskal-Wallis test, $p<0.05$ ). 
In AZN soil, a trend to decrease the percentage of RE with the increase of added peat was observed. In calcareous soils (SC), without As addition, RE was 97\%. However, samples polluted with As, due to the total inhibition of germination, did not record data on root elongation. However, it is interesting to note that the addition of peat favored RE with values even higher than $100 \%$. Only in the treatment with $600 \mathrm{mg} \cdot \mathrm{kg}^{-1}$ of As, RE was lower, but a clear increase was observed with the amount of peat added. For SNC soils, RE was $>100 \%$ in SNC-0-0, while it decreased significantly with the addition of As, SNC-300-0 (15.7\%), and SNC-600-0 (3.3\%). Moreover, peat addition to the reference soil SNC caused a significant decrease in RE. In the treatments with $2 \%$ and $5 \%$ peat addition, there were no statistically significant differences in the RE values. However, when $2 \%$ of peat was added, there was an increasing trend in RE; while, when 5\% was added, RE was reduced not significantly (Figure 3).

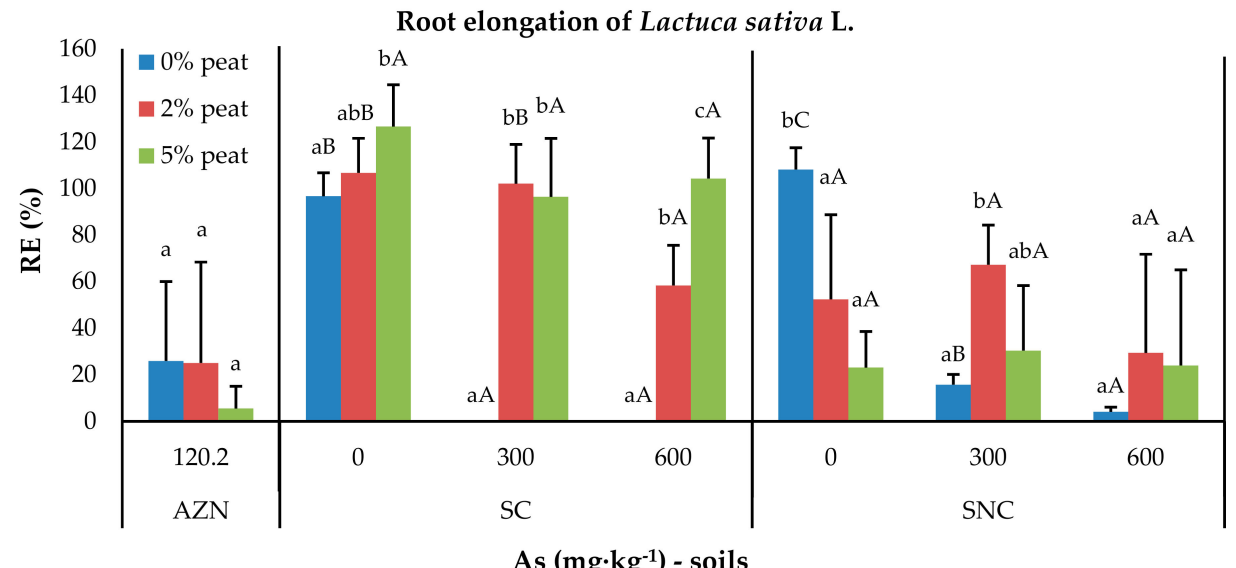

Figure 3. Lactuca sativa L. root elongation (RE\%) in the soils with different treatments. Lowercase letters indicate statistically significant differences for each treatment with different peat additions; and capital letters among the different treatments with As for the same peat content (Kruskal-Wallis test, $p<0.05$ ). Values higher than $100 \%$ indicate hormesis.

\subsection{Relation between Soil Properties and Their Recovery}

In SC samples, higher As solubility (Table 2) is related to soil toxicity by the endpoints used in toxicity bioassays (BR, SG, and RE) $(p<0.01)$. However, the addition of peat improves the three endpoints with a high degree of significance $(p<0.01)$. While, in the SNC and AZN samples, with no or few carbonates, the treatment with peat only shows a direct correlation $(p<0.01)$ with the respiration bioassay (BR). In both soil samples, iron oxides (Fed and Feo) were inversely correlated with water-soluble As concentration $(p<0.01)$, whereas other soil properties such as OC and CEC were directly correlated. Note that in these cases, the behavior of As pollution on the Fed and Feo content was uneven, with no correlation in SNC samples, and high direct correlation $(p<0.01)$ in the case of the AZN samples (Table 3).

Table 3. Spearman correlations between different soil samples, remediation treatment with peat, and the solubility of As in soils.

\begin{tabular}{|c|c|c|c|c|c|c|c|c|c|c|c|c|}
\hline Var & ibles & Peat & $\mathrm{RE}^{2}$ & $\mathrm{SG}^{3}$ & BR $^{4}$ & $\mathrm{EC}^{5}$ & $\mathrm{pH}^{6}$ & $\mathrm{OC}^{7}$ & $\mathrm{CEC}^{8}$ & Fed $^{9}$ & Feo ${ }^{10}$ & BD $^{11}$ \\
\hline \multirow[b]{2}{*}{ AZN } & Peat & - & - & - & $0.986 * *$ & $0.993^{* *}$ & $-0.761 * *$ & $0.971^{* *}$ & 0.988 ** & $-0.933^{* *}$ & $-0.968 * *$ & -0.999 ** \\
\hline & $A s_{W}{ }^{1}$ & $-0.787^{* *}$ & - & - & $-0.770^{* *}$ & $-0.803^{* *}$ & 0.661 * & $-0.739 *$ & $-0.792 * *$ & $0.778^{* * *}$ & $0.766^{* *}$ & $0.801 * *$ \\
\hline \multirow[b]{2}{*}{ SC } & Peat & - & $0.662 * *$ & $0.583 * *$ & 0.839 ** & - & -0.733 ** & $0.944^{* *}$ & 0.994 ** & 0.916 ** & $0.987^{* *}$ & $-0.824^{* *}$ \\
\hline & $\mathrm{As}_{\mathrm{W}}{ }^{1}$ & $-0.558^{* *}$ & $-0.828^{* *}$ & $-0.913^{* *}$ & $-0.742 * *$ & - & 0.896 ** & -0.521 ** & $-0.550 * *$ & $-0.346^{* *}$ & $-0.550 * *$ & - \\
\hline \multirow[b]{2}{*}{ SNC } & Peat & - & - & - & $0.916^{* *}$ & $0.452 *$ & - & $0.999 * *$ & 0.939 ** & $-0.874^{* *}$ & $-0.918^{* *}$ & $-0.994^{* *}$ \\
\hline & $A s_{W}{ }^{1}$ & -0.492 ** & - & - & $-0.559^{* *}$ & - & $0.557^{* *}$ & -0.490 ** & -0.461 ** & - & - & $0.472 * *$ \\
\hline
\end{tabular}

${ }^{1}$ water-soluble As concentration; ${ }^{2}$ Lactuca sativa L. root elongation; ${ }^{3}$ Lactuca sativa L. seed germination; ${ }^{4}$ basal soil respiration rates; ${ }^{5}$ soil electrical conductivity $(1: 5) ;{ }^{6}$ soil $\mathrm{pH}(1: 2.5) ;{ }^{7}$ organic carbon content; ${ }^{8}$ cation-exchange capacity; ${ }^{9}$ free oxides iron; ${ }^{10}$ amorphous iron; ${ }^{11}$ bulk density. ${ }^{*} p<0.05 ;{ }^{* *} p<0.01$. 


\section{Discussion}

According to the different doses of peat added, we observed that the adsorption processes on colloidal fractions of the soils played a key role in the As solubility. Although the cation exchange capacity (CEC) and the organic carbon (OC) content of the analyzed soil samples was low, peat additions increased the soil OC content, as well as the total humic extract and humic and fulvic acids, which provides an important content of reactive colloidal fractions that allow the complexation of the different chemical forms of As (mainly arsenates) [58]. The additions of $2 \%$ and $5 \%$ of peat enhance arsenic retention above $98 \%$ in most cases (except in AZN), thus reducing its solubility. These results are consistent with other studies proposing the use of peatland materials for the decontamination of waters polluted with As and other PHEs, from, e.g., gold mines in Finnish Lapland [38] or Northern England [59], among others. In the present study, soil properties such as $\mathrm{pH}$, iron oxides content (Feo) and OC are essential to As retention probably due to the influence they exert on the control of speciation, bioavailability and solubility of As in soils $[60,61]$. Soil $\mathrm{pH}$ controls strongly the adsorption processes of the arsenic in the soil [62]. Authors such as Jones et al. [63], Simón et al. [64], and Tyler and Olsson [65], among others, agree that within the soil $\mathrm{pH}$ range (3.8 to 6.3), arsenic is more easily adsorbed, while arsenic precipitation could decrease from $\mathrm{pH}>6.5$. These data agree with the obtained results, since the different treatments with As, both in the SC and SNC soil samples, reveal a slight tendency to increase the As solubility when the $\mathrm{pH}$ of the solutions increases. For example, in non-calcareous soil samples (SNC) polluted with 300 and $600 \mathrm{mg} \cdot \mathrm{kg}^{-1}$ As, without peat additions, the As $\mathrm{W}_{\mathrm{W}}$ concentration is lower with respect to calcareous soil samples (SC) with a basic character. This, in addition to the action of iron oxides, is because the $\mathrm{pH}$ in $\mathrm{SNC}$ is below 6.5. However, this increase in solubility is minimal since it is damped by the action of remediation with peat. Thus, when the $\mathrm{pH}_{\mathrm{W}}$ of the solution is basic and $\mathrm{Ca}^{2+}$ dominates in the cation exchange complex, it plays an important role in the As adsorption promoting binding bridge between the forms of arsenate and the humic substances of the peat, decreasing the As solubility, as it was observed in the SC samples, by the formation of organo-mineral complexes [66]. On the other hand, in the case of SNC samples, the acidic pH of the solution and the higher content of iron oxides, allow the co-precipitation of As with Fe and peat, thereby justifying the decrease in the As solubility, compared to the samples not treated with peat. Coinciding with Mukwaturi [67], the added organic matter is likely to play an important role in the formation of complexes between organic matter, Fe (III) and As, leading to an immobilization of the arsenic. However, without peat additions, the content of $\mathrm{As}_{\mathrm{W}}$ was much lower than that added, which shows the greater retention power that iron oxides perform compared to carbonates coinciding with the stated by Kabata-Pendias and Pendias [5] and Pierce and Moore [68]. In fact, in anthropogenically polluted soil samples (AZN), although the As $\mathrm{s}_{\mathrm{T}}$ concentration was $120.2 \mathrm{mg} \cdot \mathrm{kg}^{-1}$, it showed a low As solubility that could be largely controlled by the high amount of iron oxides present.

The observed decrease in As solubility showed positive results in the microbial activity of the soils, according to Spearman's correlation. However, this increase in microbial activity measured by basal soil respiration appears to be related to the addition of peat rather than the consequent reduction in As solubility; as the addition of peat improves physicochemical properties such as OC content and porosity (Po), and activates soil biota [69]. Kumpiene et al. [70], stating that peat amendments in soils polluted with As and high levels of Fe do not show toxicity to microorganisms, and, therefore, it is the most efficient method of reducing As dissolved in water retained in soil pores and in depth, most likely as a result of low soil density and good air diffusion in the soil, as could be deduced for AZN soil samples. Similarly, Niemeyer [71] obtained a good positive correlation between added organic amendments and basal respiration. However, other researchers maintained that the respiration of certain microorganisms can be reduced by humus-rich peat extract and concluded that they can have a toxic effect [72].

In the Lactuca sativa L. phytotoxicity test, the calcareous samples (SC), where the seeds do not germinate at any of the As levels of pollution when they are treated with peat, showed a clear positive response in seed germination (SG) and root elongation (RE), even higher than that obtained in the 
controls. However, in the samples with no or low carbonates (SNC and AZN), peat addition did not have a positive influence on SG and, consequently, on RE. Conversely, the addition of peat to SNC and AZN on the Lactuca sativa L. bioassay showed a negative effect probably caused by the toxic role that polyphenolic compounds such as lariciresinol-sesquilignan, which is found at a high level in the peat, can play. In this sense, Nishiwaki et al. [73] examined the lariciresinol stereoisomers effect on the growth of plants like Lactuca sativa L., and observed that most of the diastereomers reduced the growth of Lactuca sativa L. at a rate between $-20.7 \%$ and $-1.6 \%$. Likewise, Cutillo et al. [74] observed inhibition of germination of Lactuca sativa L. between $50 \%$ and $75 \%$ at low concentrations of various derivatives of lignans. A toxic effect caused by polyphenolic compounds that appear to be concealed when calcium carbonate is present, as it does not occur in carbonate soil samples.

Finally, if we compare the influence that the peat dose added had in the bioassays, we observed that in calcareous soil (SC) samples, 5\% peat slightly improved the respiration rate in soils with high pollution $\left(600 \mathrm{mg} \cdot \mathrm{kg}^{-1} \mathrm{As}\right.$ ) compared to the $2 \%$ peat dose. However, this fact is much more prominent in the samples of non-calcareous soil (AZN and SNC) for the proportion of $5 \%$ peat in both levels of pollution by As, which agrees with what has been reported by other authors studying the influence of iron oxides rich-amendments, like the peat, in the restoration of As-polluted mine soils [75]. Likewise, the addition of $5 \%$ peat is much more effective than the $2 \%$ in terms of root elongation for Lactuca sativa L. in calcareous soil (SC) since it buffers the phytotoxic effects of the polyphenolic compounds even at the $600 \mathrm{mg} \cdot \mathrm{kg}^{-1}$ As level of the SC samples. However, for non-calcareous soils, the addition of a higher dose of peat has a large negative effect on SG and RE that does not compensate for the greater reduction in the As solubility. Taking into consideration all this, and that the reduction in As solubility achieved with the addition of $5 \%$ is greater than with the addition of $2 \%$, although, without statistical significance, the dose of peat to be added as the most recommended amendment for calcareous soils is $5 \%$, while for non-calcareous soils it is $2 \%$ since it reduces the solubility and the phytotoxic effect of polyphenolic compounds is less severe.

\section{Conclusions}

The application of peat as an organic amendment in As-polluted soils showed high efficiency in fixing As in both natural and artificially polluted soils, regardless of the presence of calcareous properties in the soils. While soils fix some of the added As, increasingly with higher iron oxide content in the soil, additions of $2 \%$ and $5 \%$ of peat greatly enhance arsenic retention, with values above $98 \%$ in most cases. Peat addition increases OC, total humic extract, and humic and fulvic acids, providing important colloidal reactive fractions that allow the complexation of the As compounds, reducing As solubility. Soil As toxicity differs according to soil properties and peat addition. Biological response to arsenic additions was worse (lower soil respiration and inhibition of Lactuca sativa L. seed germination) in calcareous soils than in non-calcareous soils, and the former soils showed the greatest improvement in biological response by lowering As toxicity with peat amendments. In fact, in non-calcareous soils, peat addition has a negative effect on the biological response since peat contains large quantities of polyphenolic compounds such as lariciresinol-sesquiligninan that have a phytotoxic effect, which in the presence of carbonates appears to be concealed; thus additional studies are needed to assess the potential toxicity of the use of peat as an organic amendment and to prevent hazards derived from the environmental management of the As-polluted soils. Since, although both doses of peat tested ( $2 \%$ and $5 \%$ ) drastically reduced As mobility in calcareous soils, the $5 \%$ dose is the most recommended due to the great reduction of As and the absence of phytotoxic effect by polyphenolic compounds; while, in non-calcareous soils, the recommended dose is $2 \%$, although peat amendment should be added carefully in these soils to avoid phytotoxic effects.

Supplementary Materials: The following are available online at http://www.mdpi.com/2075-163X/10/11/968/s1, Figure S1: Chromatogram of peat-Determination of polyphenolic profile of the peat.

Author Contributions: Conceptualization: F.J.M.G., M.S.A., F.J.M.P., A.R.-F.; methodology: F.J.M.G., M.S.A., F.J.M.P., A.R.-F.; validation: A.A.-G., M.G.-C., F.J.M.G., A.R.-F.; formal analysis: F.J.M.G., M.G.-C., A.R.-F., A.A.-G.; 
investigation: M.G.-C., A.R.-F., A.A.-G., F.J.M.G.; resources: F.J.M.G., M.S.A., F.J.M.P., A.R.-F.; data curation: F.M.G., M.S.A., A.R.-F., M.G.-C.; writing-original draft preparation: F.J.M.G., A.A.-G., M.S.A.; writing-review and editing: A.A.-G., A.R.-F., M.G.-C., M.S.A., F.J.M.P., F.J.M.G.; visualization: F.J.M.G., A.R.-F., M.G.-C., A.A.-G.; supervision: F.J.M.P., F.M.G., M.S.A., A.R.-F.; project administration: F.J.M.G., F.J.M.P., M.S.A.; funding acquisition: F.J.M.P., M.S.A., F.J.M.G., A.A.-G. All authors have read and agreed to the published version of the manuscript.

Funding: This work was supported by the Research Project RTI 2018-094327-B-I00 and the Grant FPU-18/02901 (Spanish Ministry of Science, Innovation and Universities).

Conflicts of Interest: The authors declare no conflict of interest.

\section{References}

1. Mirsal, I.A. Soil Pollution. Origin, Monitoring and Remediation, 2nd ed.; Springer: Berlin/Heidelberg, Germany, 2008; ISBN 9783540707752.

2. Nagajyoti, P.C.; Lee, K.D.; Sreekanth, T.V.M. Heavy metals, occurrence and toxicity for plants: A review. Environ. Chem. Lett. 2010, 8, 199-216. [CrossRef]

3. Palansooriya, K.N.; Shaheen, S.M.; Chen, S.S.; Tsang, D.C.W.; Hashimoto, Y.; Hou, D.; Bolan, N.S.; Rinklebe, J.; Ok, Y.S. Soil amendments for immobilization of potentially toxic elements in contaminated soils: A critical review. Environ. Int. 2020, 134, 105046. [CrossRef]

4. Pavel, L.V.; Gavrilescu, M. Overview of ex situ decontamination techniques for soil cleanup. Environ. Eng. Manag. J. 2008, 7, 815-834. [CrossRef]

5. Kabata-Pendias, A.; Pendias, H. Trace Elements in Soils and Plants, 3rd ed.; CRC Press (Taylor \& Francis Group): Boca Raton, FL, USA, 2001; ISBN 0849315751.

6. Nriagu, J.O.; Bhattacharya, P.; Mukherjee, A.B.; Bundschuh, J.; Zevenhoven, R.; Loeppert, R.H. Arsenic in soil and groundwater: An overview. In Trace Metals and Other Contaminants in the Environment; Bhattacharya, P., Mukherjee, A.B., Bundschuh, J., Zevenhoven, R., Loeppert, R.H., Eds.; Elsevier Inc.: Amsterdam, The Netherlands, 2007; Volume 9, pp. 3-60. ISBN 9780444518200.

7. Beni, C.; Diana, G.; Marconi, S. Bovine milk chain in Italian farms. I. Arsenic levels in soil, gravitational and clean water, bovine diet, and milk. Agrochimica 2008, 52, 99-115.

8. Zhong, X.; Chen, Z.; Li, Y.; Ding, K.; Liu, W.; Liu, Y.; Yuan, Y.; Zhang, M.; Baker, A.J.M.; Yang, W.; et al. Factors influencing heavy metal availability and risk assessment of soils at typical metal mines in Eastern China. J. Hazard. Mater. 2020, 400, 123289. [CrossRef] [PubMed]

9. Kim, H.; Lee, M.; Lee, J.H.; Kim, K.H.; Owens, G.; Kim, K.R. Distribution and extent of heavy metal(loid) contamination in agricultural soils as affected by industrial activity. Appl. Biol. Chem. 2020, 63, 1-8. [CrossRef]

10. Fernández-Caliani, J.C. Risk-based assessment of multimetallic soil pollution in the industrialized peri-urban area of Huelva, Spain. Environ. Geochem. Health 2012, 34, 123-139. [CrossRef]

11. Wang, S.; Mulligan, C.N. Occurrence of arsenic contamination in Canada: Sources, behavior and distribution. Sci. Total Environ. 2006, 366, 701-721. [CrossRef] [PubMed]

12. Fazle Bari, A.S.M.; Lamb, D.; Choppala, G.; Bolan, N.; Seshadri, B.; Rahman, M.A.; Rahman, M.M. Geochemical fractionation and mineralogy of metal(loid)s in abandoned mine soils: Insights into arsenic behaviour and implications to remediation. J. Hazard. Mater. 2020, 399, 123029. [CrossRef]

13. De Souza Neto, H.F.; da Silveira Pereira, W.V.; Dias, Y.N.; de Souza, E.S.; Teixeira, R.A.; de Lima, M.W.; Ramos, S.J.; do Amarante, C.B.; Fernandes, A.R. Environmental and human health risks of arsenic in gold mining areas in the eastern Amazon. Environ. Pollut. 2020, 265, 114969. [CrossRef]

14. García-Carmona, M.; García-Robles, H.; Turpín Torrano, C.; Fernández Ondoño, E.; Lorite Moreno, J.; Sierra Aragón, M.; Martín Peinado, F.J. Residual pollution and vegetation distribution in amended soils 20 years after a pyrite mine tailings spill (Aznalcóllar, Spain). Sci. Total Environ. 2019, 650, 933-940. [CrossRef] [PubMed]

15. Tarvainen, T.; Reichel, S.; Müller, I.; Jordan, I.; Hube, D.; Eurola, M.; Loukola-Ruskeeniemi, K. Arsenic in agro-ecosystems under anthropogenic pressure in Germany and France compared to a geogenic As region in Finland. J. Geochem. Explor. 2020, 217, 106606. [CrossRef]

16. Ali, W.; Mao, K.; Zhang, H.; Junaid, M.; Xu, N.; Rasool, A.; Feng, X.; Yang, Z. Comprehensive review of the basic chemical behaviours, sources, processes, and endpoints of trace element contamination in paddy soil-rice systems in rice-growing countries. J. Hazard. Mater. 2020, 397, 122720. [CrossRef] [PubMed] 
17. Neal, C.; Robson, A.J. A summary of river water quality data collected within the Land-Ocean Interaction Study: Core data for eastern UK rivers draining to the North Sea. Sci. Total Environ. 2000, 251-252, 585-665. [CrossRef]

18. Díez, M.; Simón, M.; Dorronsoro, C.; García, I.; Martín, F. Background arsenic concentrations in Southeastern Spanish soils. Sci. Total Environ. 2007, 378, 5-12. [CrossRef]

19. O'Neill, P. Arsenic. In Heavy Metals in Soils; Alloway, B.J., Ed.; Springer Science \& Business Media: New York, NY, USA, 1995; pp. 105-121. ISBN 9789400744691.

20. Adriano, D.C. Arsenic. In Trace Elements in Terrestrial Environments. Biogeochemistry, Bioavailability and Risks of Metals; Adriano, D.C., Ed.; Springer Science \& Business Media: New York, NY, USA, 2001; pp. $219-261$. ISBN 9781468495058.

21. Bohn, H.L.; McNeal, B.L.; O'Connor, G.A. Soil Chemistry, 3rd ed.; John Wiley \& Sons: New York, NY, USA, 2001; ISBN 978-1-118-62923-9.

22. Kabata-Pendias, A.; Mukherjee, A.B. Trace Elements from Soil to Human; Springer Science \& Business Media: Berlin, Germany, 2007; ISBN 9783540327134.

23. Singh, R.; Singh, S.; Parihar, P.; Singh, V.P.; Prasad, S.M. Arsenic contamination, consequences and remediation techniques: A review. Ecotoxicol. Environ. Saf. 2015, 112, 247-270. [CrossRef]

24. BOJA. Boletín Oficial de la Junta de Andalucía. Decreto 18/2015, de 27 de enero, por el que se aprueba el reglamento que regula el régimen aplicable a los suelos contaminados. BOJA 2015, 38, 28-64. Available online: http://www.juntadeandalucia.es/medioambiente/web/2012_provisional/2015/reglamento_suelos_ contaminados.pdf (accessed on 3 October 2020).

25. German Federal Government. Federal Soil Protection Act of 17 March 1998 (Federal Law Gazette I p. 502 ). 1998. Available online: http://www.bmu.de/files/pdfs/allgemein/application/pdf/soilprotectionact.pdf (accessed on 3 October 2020).

26. VROM. Circular on Target and Intervention Values for Soil Remediation, Reference DBO/1999226863; Ministry of Housing Spatial Planning and the Environment: Bilthoven, The Netherlands, 2000. Available online: https://www.esdat. net/Environmental\%20Standards/Dutch/annexS_I2000Dutch\%20Environmental\%20Standards.pdf (accessed on 3 October 2020).

27. Environmental Agency. Government of the United Kingdom. In Human Health Toxicological Assessment of Contaminants in Soil. Science Report-Final SC050021/SR2; Environmental Agency: Bristol, UK, 2009; ISBN 9781844328581. Available online: https://www.claire.co.uk/information-centre/water-and-land-librarywall/44-risk-assessment/178-soil-guideline-values?showall=1 (accessed on 3 October 2020).

28. Dickinson, N.M.; Baker, A.J.M.; Doronila, A.; Laidlaw, S.; Reeves, R.D. Phytoremediation of inorganics: Realism and synergies. Int. J. Phytoremediat. 2009, 11, 97-114. [CrossRef]

29. Ali, H.; Khan, E.; Sajad, M.A. Phytoremediation of heavy metals-Concepts and applications. Chemosphere 2013, 91, 869-881. [CrossRef]

30. García-Carmona, M.; Romero-Freire, A.; Sierra Aragón, M.; Martínez Garzón, F.J.; Martín Peinado, F.J. Evaluation of remediation techniques in soils affected by residual contamination with heavy metals and arsenic. J. Environ. Manage. 2017, 191, 228-236. [CrossRef]

31. Aguilar, J.; Dorronsoro, C.; Fernández, E.; Fernández, J.; García, I.; Martín, F.; Sierra, M.; Simón, M. Arsenic contamination in soils affected by a pyrite-mine spill (Aznalcóllar, SW Spain). Water. Air. Soil Pollut. 2007, 180, 271-281. [CrossRef]

32. Shaheen, S.M.; Shams, M.S.; Khalifa, M.R.; El-Dali, M.A.; Rinklebe, J. Various soil amendments and environmental wastes affect the (im)mobilization and phytoavailability of potentially toxic elements in a sewage effluent irrigated sandy soil. Ecotoxicol. Environ. Saf. 2017, 142, 375-387. [CrossRef] [PubMed]

33. Park, J.H.; Lamb, D.; Paneerselvam, P.; Choppala, G.; Bolan, N.; Chung, J.W. Role of organic amendments on enhanced bioremediation of heavy metal(loid) contaminated soils. J. Hazard. Mater. 2011, 185, 549-574. [CrossRef] [PubMed]

34. Kumpiene, J.; Lagerkvist, A.; Maurice, C. Stabilization of $\mathrm{As}, \mathrm{Cr}, \mathrm{Cu}, \mathrm{Pb}$ and $\mathrm{Zn}$ in soil using amendmentsA review. Waste Manag. 2008, 28, 215-225. [CrossRef]

35. Sierra Aragón, M.; Nakamaru, Y.M.; García-Carmona, M.; Martínez Garzón, F.J.; Martín Peinado, F.J. The role of organic amendment in soils affected by residual pollution of potentially harmful elements. Chemosphere 2019, 237, 1-9. [CrossRef]

36. Nakamaru, Y.M.; Martín Peinado, F.J. Effect of soil organic matter on antimony bioavailability after the remediation process. Environ. Pollut. 2017, 228, 425-432. [CrossRef] 
37. González, Z.I.; Krachler, M.; Cheburkin, A.K.; Shotyk, W. Spatial distribution of natural enrichments of arsenic, selenium and uranium in a minerotrophic peatland, Gola di Lago, Canton Ticino, Switzerland. Environ. Sci. Technol. 2006, 40, 6568-6574. [CrossRef]

38. Palmer, K.; Ronkanen, A.K.; Kløve, B. Efficient removal of arsenic, antimony and nickel from mine wastewaters in Northern treatment peatlands and potential risks in their long-term use. Ecol. Eng. 2015, 75, 350-364. [CrossRef]

39. Cloy, J.M.; Farmer, J.G.; Graham, M.C.; Mackenzie, A.B. Retention of As and Sb in ombrotrophic peat bogs: Records of As, Sb, and Pb deposition at four Scottish sites. Environ. Sci. Technol. 2009, 43, 1756-1762. [CrossRef]

40. Rothwell, J.J.; Taylor, K.G.; Ander, E.L.; Evans, M.G.; Daniels, S.M.; Allott, T.E.H. Arsenic retention and release in ombrotrophic peatlands. Sci. Total Environ. 2009, 407, 1405-1417. [CrossRef]

41. Martín, F.; Simon, M.; Arco, E.; Romero, A.; Dorronsoro, C. Arsenic behaviour in polluted soils after remediation activities. In Soil Health and Land Use Management; Hernandez Soriano, M.C., Ed.; InTech: Shangai, China, 2012; pp. 201-216. ISBN 978-953-307-614-0.

42. Romero-Freire, A.; Sierra-Aragón, M.; Ortiz-Bernad, I.; Martín-Peinado, F.J. Toxicity of arsenic in relation to soil properties: Implications to regulatory purposes. J. Soils Sediments 2014, 14, 968-979. [CrossRef]

43. Simón, M.; Ortiz, I.; García, I.; Fernández, E.; Fernández, J.; Dorronsoro, C.; Aguilar, J. El desastre ecológico de doñana. Edafología 1998, 5, 153-161.

44. Romero-Freire, A.; Martin Peinado, F.J.; van Gestel, C.A.M. Effect of soil properties on the toxicity of Pb: Assessment of the appropriateness of guideline values. J. Hazard. Mater. 2015, 289, 46-53. [CrossRef]

45. Ministerio de Agricultura Pesca y Alimentación. Métodos Oficiales de Análisis. Tomo III. Plantas, Productos Orgánicos Fertilizantes, Suelos, Agua, Productos Fitosanitarios y Fertilizantes Inorgánicos; Publicaciones del Ministerio de Agricultura Pesca y Alimentación: Madrid, Spain, 1986.

46. Holmgren, G.G.S. A Rapid Citrate-Dithionite Extractable Iron Procedure. Soil Sci. Soc. Am. J. 1967, 31, $210-211$. [CrossRef]

47. Blakemore, L.C. Exchange complex dominated by amorphous material (ECDAM). In The Andisol Proposal; Smith, G.D., Ed.; Soil Bureau (Department of Scientific and Industrial Research): Wellington, New Zealand, 1978; Volume 21.

48. Kononova, M.M. Materia Orgánica del Suelo: Su Naturaleza, Propiedades y Métodos de Investigación, 1st ed.; OIKOS-TAU Ediciones: Barcelona, Spain, 1982; ISBN 8428104964.

49. Fendorf, S.; La Force, M.J.; Li, G. Heavy Metals in the Environment Temporal Changes in Soil Partitioning and Bioaccessibility. J. Environ. Qual. 2004, 33, 2049-2055. [CrossRef] [PubMed]

50. Tang, X.Y.; Zhu, Y.G.; Cui, Y.S.; Duan, J.; Tang, L. The effect of ageing on the bioaccessibility and fractionation of cadmium in some typical soils of China. Environ. Int. 2006, 32, 682-689. [CrossRef]

51. Aguilar, J.; Dorronsoro, C.; Fernández, E.; Fernández, J.; García, I.; Martín, F.; Sierra, M.; Simón, M. Remediation of As-contaminated soils in the Guadiamar river basin (SW, Spain). Water. Air. Soil Pollut. 2007, 180, 109-118. [CrossRef]

52. Abad-Valle, P.; Iglesias-Jiménez, E.; Álvarez-Ayuso, E. A comparative study on the influence of different organic amendments on trace element mobility and microbial functionality of a polluted mine soil. J. Environ. Manage. 2017, 188, 287-296. [CrossRef]

53. ISO 17155. Soil Quality. Determination Abundance Activity Soil Microflora Using Respiration Curves; International Standard ISO No.17155; International Organization for Standardization: Geneva, Switzerland, 2002. Available online: https://www.iso.org/standard/53529.html (accessed on 24 July 2020).

54. OECD. Guideline for the Testing of Chemicals. Proposal for Updating Guideline 208. Terrestrial Plant. Test.: 208: Seedling Emergence and Seedling Growth Test; Organization for Economic Cooperation and Development: Paris, France, 2003. Available online: https://www.oecd.org/chemicalsafety/testing/33653757.pdf (accessed on 24 July 2020).

55. US EPA. Ecological Effects Test. Guidelines. Seed Germination/Root Elongation Toxicity Test. OPPTS 850.4200; United States Environmental Protection Agency: Washington DC, USA, 1996; 2p. Available online: https://nepis.epa.gov/Exe/tiff2png.cgi/P100RF5I.PNG?-r+75+-g+7+D\%3A\%5CZYFILES\%5CINDEX\% 20DATA\%5C95THRU99\%5CTIFF\%5C00003181\%5CP100RF5I.TIF (accessed on 24 July 2020).

56. Torres, M.T.R. Empleo de los ensayos con plantas en el control de contaminantes tóxicos ambientales. Rev. Cubana Hig. Epidemiol. 2003, 41, 2-3. 
57. Reimann, C.; De Caritat, P. Chemical Elements in the Environment: Factsheets for the Geochemist and Environmental Scientist; Springer Science \& Business Media: Berlin/Heidelberg, Germany, 2012; ISBN 3642720161.

58. Zhang, D.-r.; Chen, H.r.; Xia, J.-1.; Nie, Z.y.; Fan, X.1.; Liu, H.-c.; Zheng, L.; Zhang, L.-j.; Yang, H.-y. Humic acid promotes arsenopyrite bio-oxidation and arsenic immobilization. J. Hazard. Mater. 2020, 384, 121359. [CrossRef]

59. Rothwell, J.J.; Taylor, K.G.; Evans, M.G.; Allott, T.E.H. Contrasting controls on arsenic and lead budgets for a degraded peatland catchment in Northern England. Environ. Pollut. 2011, 159, 3129-3133. [CrossRef] [PubMed]

60. Bissen, M.; Frimmel, F.H. Arsenic-A review. Part I: Occurrence, toxicity, speciation, mobility. Acta Hydrochim. Hydrobiol. 2003, 31, 9-18. [CrossRef]

61. Juhasz, A.L.; Naidu, R.; Zhu, Y.G.; Wang, L.S.; Jiang, J.Y.; Cao, Z.H. Toxicity issues associated with geogenic arsenic in the groundwater-soil-plant-human continuum. Bull. Environ. Contam. Toxicol. 2003, 71, 1100-1107. [CrossRef]

62. Roberts, D.; Nachtegaal, M.; Sparks, D.L. Speciation of metals in soils. In Chemical Processes in Soils; Tabatabai, M.A., Sparks, D.L., Eds.; Soil Science Society of America: Washington, DC, USA, 2005; pp. 619-654, ISBN 9780891188926.

63. Jones, C.A.; Inskeep, W.P.; Neuman, D.R. Arsenic transport in contaminated mine tailings following liming. J. Environ. Qual. 1997, 26, 433-439. [CrossRef]

64. Simón, M.; Martín, F.; García, I.; Bouza, P.; Dorronsoro, C.; Aguilar, J. Interaction of limestone grains and acidic solutions from the oxidation of pyrite tailings. Environ. Pollut. 2005, 135, 65-72. [CrossRef] [PubMed]

65. Tyler, G.; Olsson, T. Concentrations of 60 elements in the soil solution as related to the soil acidity. Eur. J. Soil Sci. 2001, 52, 151-165. [CrossRef]

66. Kong, Y.; Kang, J.; Shen, J.; Chen, Z.; Fan, L. Influence of humic acid on the removal of arsenate and arsenic by ferric chloride: Effects of $\mathrm{pH}, \mathrm{As} / \mathrm{Fe}$ ratio, initial As concentration, and co-existing solutes. Environ. Sci. Pollut. Res. 2017, 24, 2381-2393. [CrossRef]

67. Mukwaturi, M.; Lin, C. Mobilization of heavy metals from urban contaminated soils under water inundation conditions. J. Hazard. Mater. 2015, 285, 445-452. [CrossRef]

68. Pierce, M.L.; Moore, C.B. Adsorption of arsenite and arsenate on amorphous iron hydroxide. Water Res. 1982, 16, 1247-1253. [CrossRef]

69. Six, J.; Bossuyt, H.; Degryze, S.; Denef, K. A history of research on the link between (micro)aggregates, soil biota, and soil organic matter dynamics. Soil Tillage Res. 2004, 79, 7-31. [CrossRef]

70. Kumpiene, J.; Desogus, P.; Schulenburg, S.; Arenella, M.; Renella, G.; Brännvall, E.; Lagerkvist, A.; Andreas, L.; Sjöblom, R. Utilisation of chemically stabilized arsenic-contaminated soil in a landfill cover. Environ. Sci. Pollut. Res. 2013, 20, 8649-8662. [CrossRef] [PubMed]

71. Niemeyer, J.C.; Lolata, G.B.; de Carvalho, G.M.; Da Silva, E.M.; Sousa, J.P.; Nogueira, M.A. Microbial indicators of soil health as tools for ecological risk assessment of a metal contaminated site in Brazil. Appl. Soil Ecol. 2012, 59, 96-105. [CrossRef]

72. Minderlein, S.; Blodau, C. Humic-rich peat extracts inhibit sulfate reduction, methanogenesis, and anaerobic respiration but not acetogenesis in peat soils of a temperate bog. Soil Biol. Biochem. 2010, 42, 2078-2086. [CrossRef]

73. Nishiwaki, H.; Kumamoto, M.; Shuto, Y.; Yamauchi, S. Stereoselective syntheses of all stereoisomers of lariciresinol and their plant growth inhibitory activities. J. Agric. Food Chem. 2011, 59, 13089-13095. [CrossRef]

74. Cutillo, F.; D'Abrosca, B.; DellaGreca, M.; Fiorentino, A.; Zarrelli, A. Lignans and neolignans from Brassica fruticulosa: Effects on seed germination and plant growth. J. Agric. Food Chem. 2003, 51, 6165-6172. [CrossRef]

75. Abad-Valle, P.; Álvarez-Ayuso, E.; Murciego, A. Evaluation of ferrihydrite as amendment to restore an arsenic-polluted mine soil. Environ. Sci. Pollut. Res. 2015, 22, 6778-6788. [CrossRef]

Publisher's Note: MDPI stays neutral with regard to jurisdictional claims in published maps and institutional affiliations. 